\title{
Microstructure and Hardness Evolution of Al8Zn7Ni3Mg Alloy after Casting at very Different Cooling Rates
}

\author{
Pavel Shurkin ${ }^{1, *(\mathbb{D})}$, Torgom Akopyan ${ }^{1,2}{ }^{-}$, Nataliya Korotkova ${ }^{1}$, Alexey Prosviryakov ${ }^{3} \mathbb{C}^{\text {, }}$ \\ Andrey Bazlov ${ }^{3}$, Alexander Komissarov ${ }^{4}$ (D) and Dmitry Moskovskikh ${ }^{5}$ (D) \\ 1 Department of Metal Forming, National University of Science and Technology MISiS, Leninsky Ave. 4, \\ 119049 Moscow, Russia; nemiroffandtor@yandex.ru (T.A.); darkhopex@mail.ru (N.K.) \\ 2 Baikov Institute of Metallurgy and Materials Science, Russian Academy of Sciences, Leninsky Ave. 49, \\ 119991 Moscow, Russia \\ 3 Department of Physical Metallurgy of Non-Ferrous Metals, National University of Science and Technology \\ MISiS, Leninsky Ave. 4, 119049 Moscow, Russia; pro.alex@mail.ru (A.P.); bazlov@misis.ru (A.B.) \\ 4 Laboratory of Hybrid Nanostructured Materials, National University of Science and Technology MISiS, \\ Leninsky Ave. 4, 119049 Moscow, Russia; komissarov.alex@gmail.com \\ 5 Centre of Functional Nanoceramics, National University of Science and Technology MISiS, Leninsky Ave. 4, \\ 119049 Moscow, Russia; mos@misis.ru \\ * Correspondence: pa.shurkin@gmail.com
}

Received: 13 May 2020; Accepted: 5 June 2020; Published: 7 June 2020

check for updates

\begin{abstract}
In this study, we combined both a high strength $\mathrm{Al}-8 \% \mathrm{Zn}-3 \% \mathrm{Mg}$ aluminum matrix and a reinforcing contribution of $\mathrm{Al}_{3} \mathrm{Ni}$ intermetallics in $\mathrm{Al} 8 \mathrm{Zn} 7 \mathrm{Ni} 3 \mathrm{Mg}$ hypereutectic alloy with a tuned microstructure via a variation of cooling rates from $0.1 \mathrm{~K} / \mathrm{s}$ to $2.3 \times 10^{5} \mathrm{~K} / \mathrm{s}$. Using the ThermoCalc software, we analyzed the effect of nickel content on the phase equilibria during solidification and found out that $7 \% \mathrm{Ni}$ provides a formation of equal fractions of primary ( $6.5 \mathrm{vol} . \%)$ and eutectic (6.3 vol.\%) crystals of the $\mathrm{Al}_{3} \mathrm{Ni}$ phase. Using microstructural analysis, a refinement of intermetallics with an increase in cooling rate was observed. It is remarkable that the structure after solidification at $\sim 10^{3} \mathrm{~K} / \mathrm{s}$ across $1 \mathrm{~mm}$ flake casting consists of a quasi-eutectic with $1.5 \mu \mathrm{m} \mathrm{Al}_{3} \mathrm{Ni}$ fibers, while an increase in the cooling rate to $\sim 10^{5} \mathrm{~K} / \mathrm{s}$ after melt spinning leads to the formation of $50 \mathrm{~nm}$ equiaxed $\mathrm{Al}_{3} \mathrm{Ni}$ particles. Under these conditions, the alloy showed an aging response at $200{ }^{\circ} \mathrm{C}$, resulting in hardness of $200 \mathrm{HV}$ and $220 \mathrm{HV}$, respectively. After $470{ }^{\circ} \mathrm{C}$ annealing, the fibers in the $1 \mathrm{~mm}$ sample evolved to needles. However, in melt-spun ribbons, the particles were kept globular and small-sized. Overall, the results may greatly contribute to the development of new eutectic type composites for rapid solidification methods.
\end{abstract}

Keywords: composite materials; hypereutectic aluminum alloys; Al-Zn-Mg alloys; rapid solidification; eutectic; CALPHAD; microstructure; intermetallics; precipitation hardening

\section{Introduction}

Due to the growing demand in strong lightweight materials, numerous studies have been dedicated to increase aluminum alloys strength. Since the Al-Zn-Mg- $(\mathrm{Cu})$ alloys $(7 \mathrm{xxx})$ are the class of Al-based materials with the highest strength, their application has made advances for years in aircraft and space components [1,2]. The most common approaches toward the strengthening of 7xxx alloys are precipitation hardening and work hardening [3-5]. According to [6], conventional 7075 alloy may have $600 \mathrm{MPa}$ tensile strength (T6), while by using the complex alloying and processing techniques the properties can be further enhanced. For example, according to [7], the von Mises yield 
rule of the dislocation theory, based on the yield prediction of the isotropic material under complex loading condition, says that they can reach more than 1148 GPa yield strength. This value was partially confirmed in some studies [8-10], where about 700-900 MPa tensile strength was achieved as a result of a raise in the overall content $(\mathrm{Zn}+\mathrm{Mg}+\mathrm{Cu})$, addition of precipitation inoculants like $\mathrm{Ag}$ or Sc, and complex thermomechanical treatment, including cold working or severe plastic deformation. However, the increase in strength can also be achieved by creating a composite material with a high fraction of in-situ reinforcing particles [11,12]. The accelerated solidification of the alloys, such as in the case of melt spinning or selective laser melting (hereafter referred to as SLM), can minimize the decrease in ductility caused by reinforcing particles, while the strength can be significantly increased via the Orowan looping mechanism [13] or a load transfer [14]. Therefore, we find it worth considering to strengthen $\mathrm{Al}-\mathrm{Zn}-\mathrm{Mg}$ alloy using an in-situ particulate reinforcing approach which has been widely implemented for various Al-based materials.

Aluminum matrix composites (AMCs) have become popular during the last decades, and nowadays the amount of their demand grows along with the requirements for properties of products and the technology of their fabrication [15]. Most AMCs are post-produced by the introduction of ceramic particles (e.g., $\mathrm{Al}_{2} \mathrm{O}_{3}, \mathrm{SiC}, \mathrm{AlN}$, etc.) via casting methods (stir/squeeze casting), powder and granule metallurgy, combustion synthesis, etc. [15-20]. Nevertheless, their fabrication faces challenges like difficulty in producing a smaller particle size [15] and poor wettability between ceramics and molten aluminum [20]. These disadvantages cause strong restrictions on their applications, especially at a high volume of the reinforcement.

Aluminum-based alloying systems offer opportunities to fabricate AMCs reinforced by particles formed after natural (in-situ) crystallization which provide their homogenous distribution. For example, the most common commercial eutectic-based Al-Si alloys share many properties of ceramic reinforced composites [21]. Since the mechanical properties of the AMCs are tuned by controlling the type, size, morphology, and volume fraction of the filler, the prevalent number of the Al-Si in-situ composites are hypereutectic $(>12 \% \mathrm{Si})$ and fabricated using special techniques providing rapid solidification (hereafter referred to as RS methods) in order to avoid a coarse primary silicon phase and achieve a quasi-eutectic microstructure phenomena [22,23]. In this case, the strengthening is provided by the formation of a homogeneously distributed eutectic mixture.

However, the tensile properties of Al-Si composites are low (e.g., UTS $<200 \mathrm{MPa}$ for consolidated powder product [24]). Moreover, when it comes to 7xxx alloys, it is recognized that silicon is a harmful impurity since it causes $\mathrm{Mg}_{2} \mathrm{Si}$ phase formation which leads to a reduction of precipitation strengthening [25]. This statement is supported by official data presented in the Aluminium Association standard, e.g., commercial 7075 and 7068 alloys contain up to $0.4 \mathrm{wt} . \%$ and $0.12 \% \mathrm{Si}$, respectively [26].

Meanwhile, another eutectic-forming element, nickel, does not interact with zinc and magnesium. The $\mathrm{Al}_{3} \mathrm{Ni}$ compound has a tensile strength of about $2160 \mathrm{MPa}$ and an acceptable Young modulus of 116-152 GPa that makes it reasonable for reinforcing of aluminum [27]. Moreover, its orthorhombic lattice provides incoherency toward aluminum [28]. Some near eutectic $(<4 \mathrm{wt} . \% \mathrm{Ni}) \mathrm{Al}-\mathrm{Zn}-\mathrm{Mg}-\mathrm{Ni}$ based on $(\mathrm{Al})+\mathrm{Al}_{3} \mathrm{Ni}$ eutectic alloys are recognized to be promising as structural materials fabricated by casting and metal forming technologies $[29,30]$, while $\mathrm{Al}-\mathrm{Zn}-\mathrm{Mg} / \mathrm{Al}_{3} \mathrm{Ni}$ composites with a high volume of reinforcement (e.g., at hypereutectic concentrations of nickel) have not been described in depth. The enhancement of the aging rate along with $\mathrm{Al}_{3} \mathrm{Ni}$ phase volume fraction was reported in [31]. The 7005/(0-10.4 vol.\%) $\mathrm{Al}_{3} \mathrm{Ni}$ composite was prepared by metal mold gravity casting and there were particles of more than $50 \mu \mathrm{m}$ in size. Thus, their contribution into reinforcing is reasonable to be low. The approach toward refining of $\mathrm{Al}_{3} \mathrm{Ni}$ primary crystals up to $5 \mu \mathrm{m}$ by rolling was suggested in the study on 7050/(5-10 wt.\%) Ni composite [7]. It is alleged that the yield strength calculated by the Orowan equation can get $630 \mathrm{MPa}$, while the brittle fracture surface was shown. Both these papers do not consider the RS methods to obtain a quasi-eutectic structure. In an earlier research [32], the formation of the fully eutectic structure in Al-7\%Ni hypereutectic alloy after unidirectional solidification is reported. In Martínez-Villalobos et al.'s study [33], the same result on Al-8\%Ni after 
melt spinning was achieved and an effectiveness of reinforcement was shown to be due to ultrafine $\mathrm{Al}_{3} \mathrm{Ni}$ particles formation.

As for matrix, the experiments on melt-spun ribbons of Al-Zn-Mg alloys showed an opportunity of obtaining a supersaturated solid solution without prior annealing for quenching [34]. The same result was achieved after rapid solidification released during SLM of 7068 alloy along with providing precipitation hardening via the aging of as-built parts [35]. In this study, we chose the copper-free matrix system Al-8\% Zn-3\%Mg as basis related to the strongest commercial 7xxx alloys (7001, 7090, 7055, etc. [26]). We do not consider copper addition because it causes unreasonable complication of phase composition, as it is clearly shown in a pivotal research [36] on the optimization of Al-Zn-Mg-Cu-Ni alloys.

As for reinforcement, the key requirements are to possess a high enough volume of aluminides particles and an absence of the primary crystals in the structure. Thus, it is mainly desirable to obtain a fully eutectic structure on the supersaturated matrix field. To ensure a high concentration of reinforcement particles, the study is dedicated on nickel content of $7 \%$ that is substantiated in the computational section. Since the morphology of the $\mathrm{Al}_{3} \mathrm{Ni}$ phase can be tuned on the cooling rate basis, we followed the investigation path via the study of the phase diagrams and experimental simulation of cooling rate enhancement.

From the above, the current paper aims to investigate the evolution of the solidification path, structure, and hardness depending on cooling rate variation from slow to rapid solidification of the Al8Zn7Ni3Mg alloy by thermodynamic calculation and experimental study.

\section{Materials and Methods}

Initially, we investigated details of $\mathrm{Al}-8 \% \mathrm{Zn}-3 \% \mathrm{Mg}$ alloys with various nickel contents, in particular, solidification path and phase composition using the Thermo-Calc software (Version 3.1, TCAl4 Al-based alloy database, Thermo-Calc Software AB, Stockholm, Sweden) [37]. Single point equilibrium, phase diagram, property diagram, and Scheil-Goulliver solidification simulation options were used.

For the experimental section, the Al8Zn7Ni3Mg alloy was the main test material. The samples were prepared by melting high-purity aluminum $(99.99 \% \mathrm{Al})$, zinc $(99.97 \% \mathrm{Zn})$, magnesium $(99.9 \% \mathrm{Mg})$, and Al20\%Ni master alloy in a graphite-chamotte crucible using a Nabertherm K 1/13 (Nabertherm $\mathrm{GmbH}$, Lilienthal, Germany) resistance furnace in an air atmosphere. The melt temperature was kept at $850{ }^{\circ} \mathrm{C}$ and the total time of the melting process was about $90 \mathrm{~min}$. The Al20\%Ni master alloy was mixed into the molten aluminum using a graphite stick. Before casting, the melt was purified by dry $\mathrm{C}_{2} \mathrm{Cl}_{6}$ powder. The chemical composition as determined by spectral analysis is presented in Table 1 .

Table 1. Chemical composition of the experimental alloy.

\begin{tabular}{ccccc}
\hline \multirow{2}{*}{ Designation } & \multicolumn{4}{c}{ Concentrations, wt. \% } \\
\cline { 2 - 5 } & $\mathbf{Z n}$ & $\mathbf{M g}$ & $\mathbf{N i}$ & $\mathbf{A l}$ \\
\hline A18Zn7Ni3Mg & 7.79 & 3.13 & 7.16 & Balance \\
\hline
\end{tabular}

In order to obtain a variety of cooling rates, we provided different solidification conditions. A portion of molten metal $\sim 50 \mathrm{~g}$ was solidified in the furnace, and thus the lowest cooling rate was achieved (FC sample). Three cooling conditions were provided via casting. We obtained cylindrical samples of $30 \mathrm{~mm}$ and $5 \mathrm{~mm}$ in diameter, and a thin flake of less than $1 \mathrm{~mm}$ via pouring onto a cold steel heat sink. The highest cooling rate was induced using a melt spinning (MS sample) of experimental alloy ingot via pouring a molten metal onto a rotating copper wheel of DVX-II apparatus (Dexing Magnet Tech. CO. Ltd., Xiamen, China) in an argon gas atmosphere. The linear rotation speed of the copper wheel was $30 \mathrm{~m} / \mathrm{s}$. A general view of the samples is demonstrated in Figure 1 . 

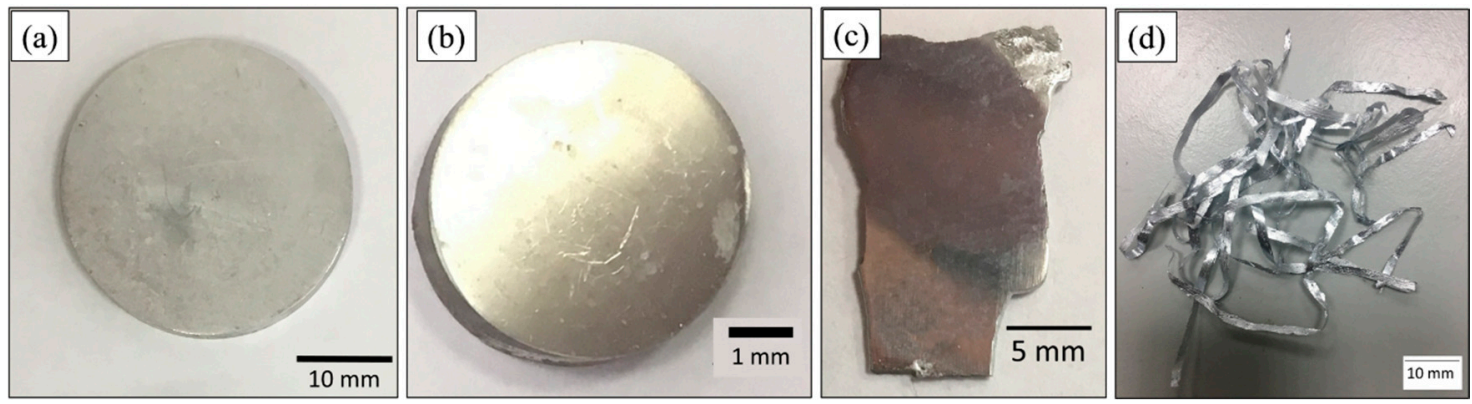

Figure 1. Experimental cast samples and melt-spun ribbons: (a) $30 \mathrm{~mm}$ cast sample; (b) $5 \mathrm{~mm}$ cast sample; (c) $1 \mathrm{~mm}$ cast sample; (d) melt-spun ribbon.

The microstructure was examined by optical microscopy (OM, Axio Observer MAT, Carl Zeiss Microscopy $\mathrm{GmbH}$, Oberkochen, Germany), scanning electron microscopy (SEM, TESCAN VEGA3, Tescan Orsay Holding, Brno, Czech Republic) with an electron microprobe analysis system (EMPA, Oxford Instruments plc, Abingdon, UK), and the Aztec software (Version 3.0, Oxford Instruments plc, Abingdon, UK). The metallographic samples were ground with $\mathrm{SiC}$ abrasive paper and polished with $1 \mu \mathrm{m}$ diamond suspension. A total of $1 \%$ hydrogen fluoride (HF) water solution was used for etching. To investigate the structure of the melt-spun ribbons, we used transmission electron microscopy (TEM, JEM-2100, JEOL Ltd., Tokyo, Japan).

The size of the dendritic cells (dendritic parameter, $d$ ), as well as of the intermetallics, was experimentally determined using metallography from high-contrast microstructural images processed with the appropriate software, ImageJ (National Institutes of Health, Bethesda, MD, USA). The Horizontal Lines option was used for implementing the stereological method of measuring the relative length of the phase regions. To obtain reliable data, we analyzed at least 10 fields in the microstructure for defining the content of each structural component. The experimental dendritic parameter data were used for evaluating the cooling rate in the alloy crystallization temperature range using a well-known empirical relationship [38]:

$$
V_{c}=(A / d)^{1 / n},
$$

where $V_{c}$-cooling rate upon solidification in $\mathrm{K} / \mathrm{s}, d$-dendritic parameter in $\mu \mathrm{m}$ and $A$, $n$-material-dependent constants.

Since we do not take determination of the precise material dependent constants as a mandatory, they were taken from [20] for high-strength Al-Zn-Mg-Cu alloys as $A=100$ and $n=1 / 3$.

Some samples were selectively subjected to a T5 heat treatment (aging at $200{ }^{\circ} \mathrm{C}$ for $1 \mathrm{~h}$ without prior quenching) and a T4 heat treatment $\left(470^{\circ} \mathrm{C}\right.$ for $\left.1 \mathrm{~h}\right)$. To control the properties evolved, a Vickers' hardness test at a load of $10 \mathrm{~g}(0.1 \mathrm{~N})$ and $5 \mathrm{~s}$ dwell (for the MS sample), and at a load of $1 \mathrm{~kg}(10 \mathrm{~N})$ and a dwell time of $10 \mathrm{~s}$ (for other samples) was used.

\section{Results and Discussion}

\subsection{Computational Section}

The polythermal section shown in Figure 2a indicates that under equilibrium conditions the nickel addition to the Al- $8 \% \mathrm{Zn}-3 \% \mathrm{Mg}$ alloy significantly influences on the solidification path shifting to a hypereutectic manner at over $3.6 \% \mathrm{Ni}$. The Al-Zn-Mg-Ni system is convenient to study due to a lack of interaction between $\mathrm{Al}-\mathrm{Zn}-\mathrm{Mg}$ and $\mathrm{Al}-\mathrm{Ni}$ systems. Thus, all of $\mathrm{Zn}$ and $\mathrm{Mg}$ are bonded into the $\mathrm{T}$ phase $\left(\mathrm{Al}_{2} \mathrm{Mg}_{3} \mathrm{Zn}_{3}\right)$ which is responsible for precipitation hardening of alloys with a $\mathrm{Zn} / \mathrm{Mg}$ atomic mass ratio of less than 1 [39]. The liquidus line rises and the equilibrium solidus decreases slightly with an increase in nickel concentration in hypereutectic alloys. The Al8Zn7Ni3Mg alloy shows an experimental liquidus and solidus temperature of 665 and $520^{\circ} \mathrm{C}$, respectively. However, 
the Scheil-Goulliver simulation showed that the solidification range is much higher than the one in equilibrium condition and it ends with the proceeding of the $\left[(\mathrm{Al})+\mathrm{Al}_{3} \mathrm{Ni}+\mathrm{T}\right]$ reaction at a temperature of $478^{\circ} \mathrm{C}$ (dotted line in the polythermal section). The temperatures, determined by thermal analysis using a single chromel-alumel thermocouple submerged into the melt, sufficiently agree with the calculated data that especially fair for non-equilibrium solidus. The reactions $\left[\mathrm{L} \rightarrow \mathrm{Al}_{3} \mathrm{Ni}\right]$ at $659{ }^{\circ} \mathrm{C},\left[\mathrm{L}+\mathrm{Al}_{3} \mathrm{Ni}+(\mathrm{Al})\right]$ at $624{ }^{\circ} \mathrm{C}$, and $\left[\mathrm{L}+\mathrm{Al}_{3} \mathrm{Ni}+(\mathrm{Al})+\mathrm{T}\right]$ at $478^{\circ} \mathrm{C}$ are detected. On the one hand, such a low solidus intrinsic to $7 x x x$ alloys deteriorates their hot cracking tolerance in some RS methods, like SLM [40]. On the other hand, having a high volume of eutectic may lead to an improvement of brittleness due to cracking healing in the solid-liquid state [41].
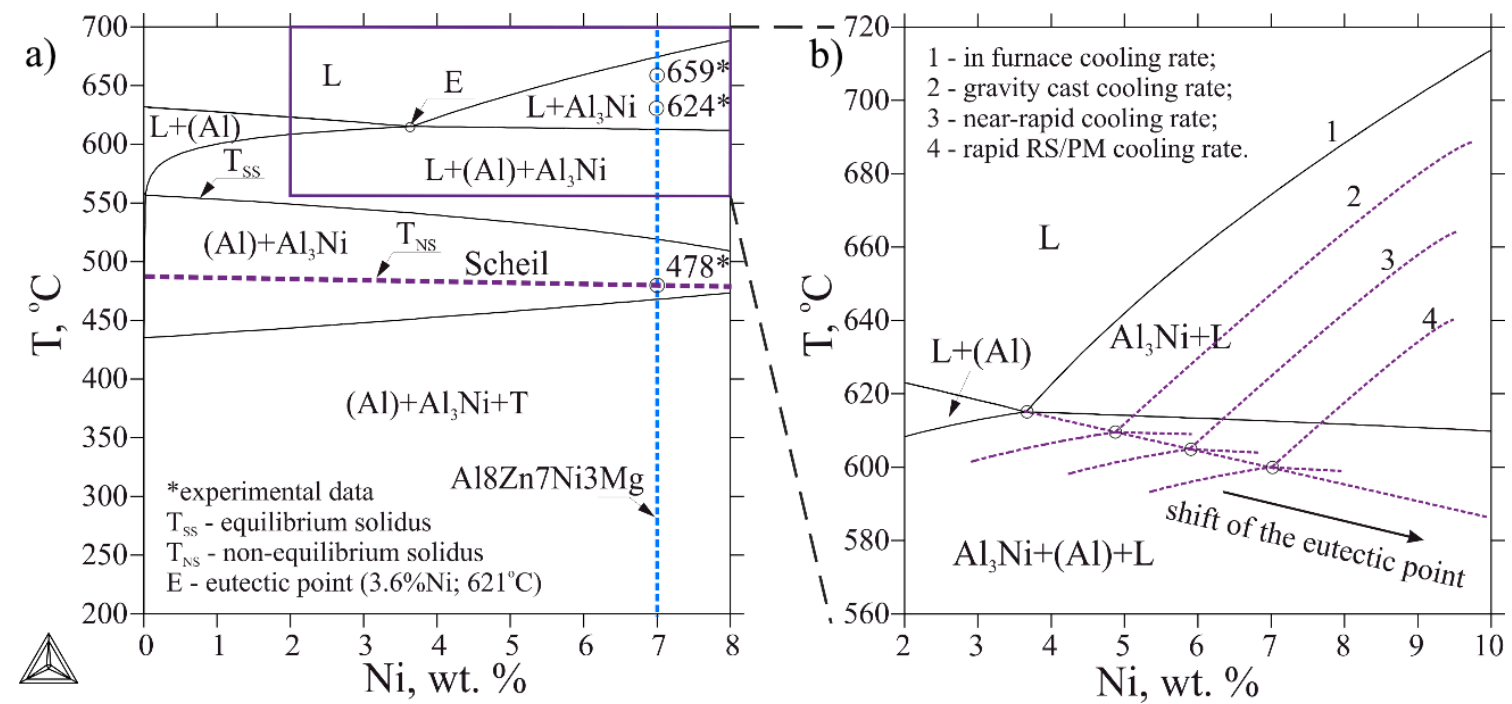

Figure 2. (a) Polythermal section of a $\mathrm{Al}-\mathrm{Zn}-\mathrm{Mg}-\mathrm{Ni}$ system at $8 \% \mathrm{Zn}$ and $3 \% \mathrm{Mg}$ with marked non-equilibrium solidus calculated by Scheil-Goulliver simulation and (b) schematic representation of the solidification path shift as a result of an increase in the cooling rate.

In addition, Figure $2 \mathrm{~b}$ schematically shows how the binary eutectic point shift depends on the cooling rate. According to [42], under high undercooling, diffusion in the liquid phase may be hindered causing local changes in composition and difference in local solidification rates. Under this condition, the sustainable extension of $\mathrm{Zn}$ and $\mathrm{Mg}$ solubility in the (Al) matrix can be expected [34]. In addition, the temperatures of liquidus and solidus may be lower than the equilibrium ones. It is anticipated that the experimental samples may solidify via different paths, causing a variety of structures from highly-hypereutectic to hypoeutectic, including eutectic manner if the two phases would solidify simultaneously in a diffusion coupled fashion. These microstructures can be qualified as quasi-structures, because the corresponding alloy is hypereutectic in general.

According to Figure $2 \mathrm{a}$, the solvus temperature corresponding to the dissolution of the $\mathrm{T}$ phase $\left(\mathrm{Al}_{2} \mathrm{Mg}_{2} \mathrm{Zn}_{3}\right)$ increases along with nickel content and therefore the $\left[(\mathrm{Al})+\mathrm{Al}_{3} \mathrm{Ni}\right]$ area is narrowing as well as the suitable range of quenching temperatures. We chose a temperature of $470{ }^{\circ} \mathrm{C}$ as a conventional temperature for a solid solution treatment of 7xxx alloys [1].

Figure 3 a shows how the (Al) solid solution composition evolves at $470{ }^{\circ} \mathrm{C}$ depending on nickel content. It is assumed to be the same after rapid solidification. According to the (Al) matrix composition, we simulated its decomposition at the chosen aging temperature of $200{ }^{\circ} \mathrm{C}$ as a volume fraction of precipitation products both $\mathrm{T}^{\prime}$ and $\mathrm{M}^{\prime}$. The graph shows that nickel addition contributes to a gradual growth of $\mathrm{Zn}$ and $\mathrm{Mg}$ content in (Al) matrix, as well as precipitates volume, respectively. The solid solution of the experimental Al8Zn7Ni3Mg alloy composes $9.6 \% \mathrm{Zn}$ and $3.6 \% \mathrm{Mg}$, promoting precipitations of 9.6 vol.\% both $\mathrm{T}^{\prime}$ and $\mathrm{M}^{\prime}$ dispersoids responsible for matrix hardening. It is clearly seen that the $(\mathrm{Al})$ solid solution composition and volume of dispersoids see a plateau $(9.7 \% \mathrm{Zn}$ and 
$3.7 \% \mathrm{Mg}$ in ( $\mathrm{Al})$ and $10.1 \mathrm{vol} \%$ of precipitates) at over $7.5 \% \mathrm{Ni}$. The further addition of nickel may cause an undesirable end of solidification via ternary eutectic $\left[(\mathrm{Al})+\mathrm{Al}_{3} \mathrm{Ni}+\mathrm{T}\right]$ leading to the appearance of an additional quantity of the T-phase in the structure undissolved in aluminum. That way, a higher amount of nickel seems to be unreasonable.

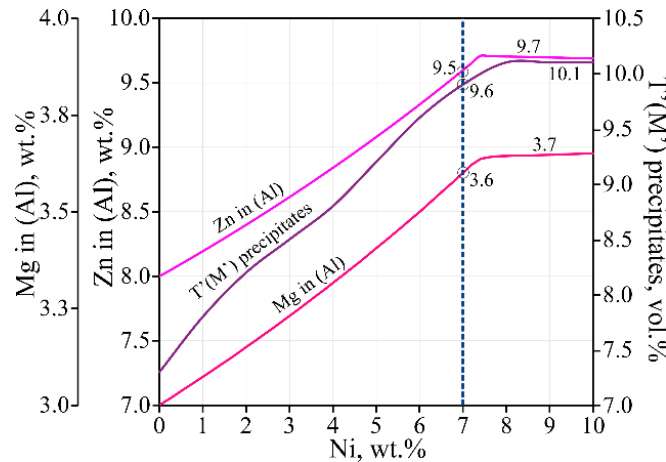

(a)

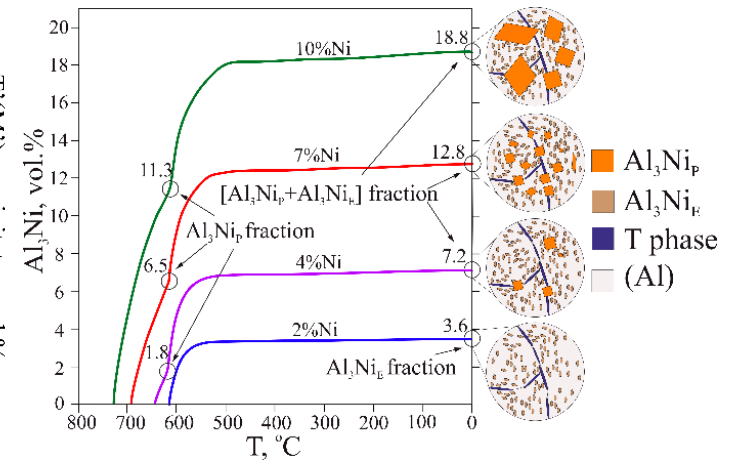

(b)

Figure 3. (a) Composition of the (Al) solid solution at $470{ }^{\circ} \mathrm{C}$ and corresponding volume fraction of $\mathrm{T}^{\prime}$ $\left(\mathrm{M}^{\prime}\right)$ precipitates at $200{ }^{\circ} \mathrm{C}$ depending on nickel content in $\mathrm{Al}-8 \% \mathrm{Zn}-3 \% \mathrm{Mg}$; (b) relationship between volume fraction of $\mathrm{Al}_{3} \mathrm{Ni}$ phase and temperature at various nickel contents in $\mathrm{Al}-8 \% \mathrm{Zn}-3 \% \mathrm{Mg}$ alloy and schematic display of the structure evolution.

Figure $3 \mathrm{~b}$ shows the volume fraction of the $\mathrm{Al}_{3} \mathrm{Ni}$ phase in $\mathrm{Al}-8 \% \mathrm{Zn}-3 \% \mathrm{Mg}-x \mathrm{Ni}(x=2 \%, 4 \%$, $7 \%, 10 \%$ ) alloy depending on the temperature under equilibrium conditions. In hypereutectic alloys, the formation of two types of intermetallics is possible. The primary phase $\left(\mathrm{Al}_{3} \mathrm{Ni}_{\mathrm{P}}\right)$ appears before the aluminum solid solution. Then it progresses with eutectic particles $\left(\mathrm{Al}_{3} \mathrm{Ni}_{\mathrm{E}}\right)$ formation along with aluminum. As we schematically represented, the $\mathrm{Al}_{3} \mathrm{Ni}_{\mathrm{E}}$ type nucleates as disperse particles, while the $\mathrm{Al}_{3} \mathrm{Ni}_{\mathrm{P}}$ type commonly has a faceted morphology. While at $2 \%$ and $4 \% \mathrm{Ni}$ the volume of the reinforcement is significantly scarce $(3.6 \%$ and $7.2 \%)$, at increasingly hypereutectic concentrations $(10 \% \mathrm{Ni})$ the volume fraction is superior $(18.8 \%)$, but the $\mathrm{Al}_{3} \mathrm{Ni}_{\mathrm{P}}$ fraction is dominant $(11.3 \%)$. On this occasion, the suppression of the pre-eutectic stage may be not accomplished in our experimental conditions. Barclay et al. [32], who first achieved a quasi-eutectic structure in Al-Ni hypereutectic alloys by the RS method, found that $\mathrm{Al}-10 \% \mathrm{Ni}$ alloy requires a five times higher solidification rate than $\mathrm{Al}-7 \% \mathrm{Ni}$ alloy for achieving suppression of the $\mathrm{Al}_{3} \mathrm{Ni}$ primary crystallization.

Thus, the experimental Al8Zn7Ni3Mg alloy exhibits appropriate volume fraction of intermetallics $(12.8 \%)$ composed of balanced eutectic $(6.3 \%)$ and primary $(6.5 \%)$ crystals. In addition to that, it shows the highest promise for precipitation hardening, a low inter-particles spacing is anticipated, taking into account positive results on binary alloys [32,33].

\subsection{Solidification Path and Structure Analysis}

The results of the cooling rate estimation are shown in Table 2, as well as the change in microstructural peculiarities pertaining to the dendritic parameter and $\mathrm{Al}_{3} \mathrm{Ni}$ intermetallics size. As can be seen, an increase in the cooling rate drives a refinement of primary crystals up to the ultimate suppression of the pre-eutectic stage after cooling at more than $10^{3} \mathrm{~K} / \mathrm{s}$.

The results are supported by a general view of microstructure evolution from a slow rate furnace-cooled sample to rapidly cooled melt-spun ribbons (Figure 4). In $\mathrm{OM}$ images, the $\mathrm{Al}_{3} \mathrm{Ni}$ phase is visible as brown inclusions embedded into the light matrix of the $\mathrm{Al}$ ) solid solution, and otherwise, in the SEM image light intermetallics are incorporated into the dark matrix. Generally, the evolution allows to estimate the formation of a quasi-eutectic structure under an increase in the cooling rate. 
Table 2. Microstructure peculiarities of the A18Zn7Ni3Mg alloy depending on the cooling rate.

\begin{tabular}{|c|c|c|c|c|}
\hline $\begin{array}{l}\text { Experimental } \\
\text { Sample }\end{array}$ & $\begin{array}{l}\text { Dendritic Parameter } \\
(\text { d })^{1}, \mu \mathrm{m}\end{array}$ & Cooling Rate $\left(V_{c}\right)^{2}, \mathrm{~K} / \mathrm{s}$ & $\mathrm{Al}_{3} \mathrm{Ni}$ Size Range ${ }^{1}, \mu \mathrm{m}$ & $\begin{array}{l}\mathrm{Al}_{3} \mathrm{Ni} \text { Median Size }{ }^{1} \\
\mu \mathrm{m}\left(\mathrm{Al}_{3} \mathrm{Ni}_{\mathrm{E}} / \mathrm{Al}_{3} \mathrm{Ni}_{\mathrm{P}}\right)\end{array}$ \\
\hline FC & $198 \pm 31$ & 0.1 & $30-351$ & $12 / 225$ \\
\hline $5 \mathrm{~mm}$ cast & $19 \pm 6$ & 133 & $5-43$ & $2 / 7$ \\
\hline $1 \mathrm{~mm}$ cast & $9 \pm 2$ & $1.4 \times 10^{3}$ & $1-3$ & $1.5 /-$ \\
\hline
\end{tabular}

${ }^{1}$ determined using image analysis software; ${ }^{2}$ calculated using the Equation (1).

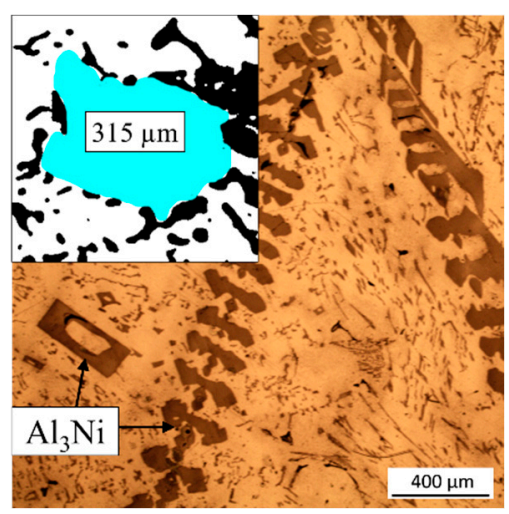

(a)

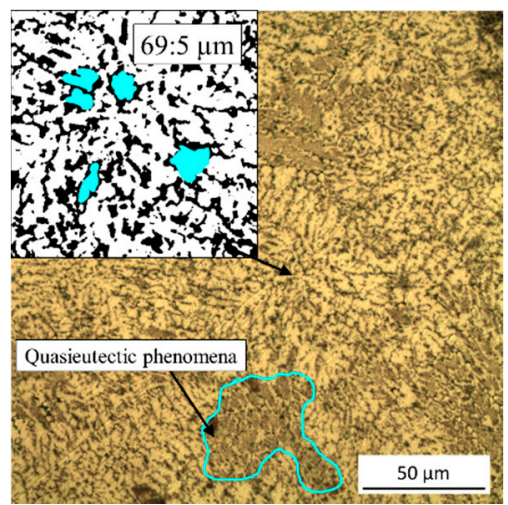

(d)

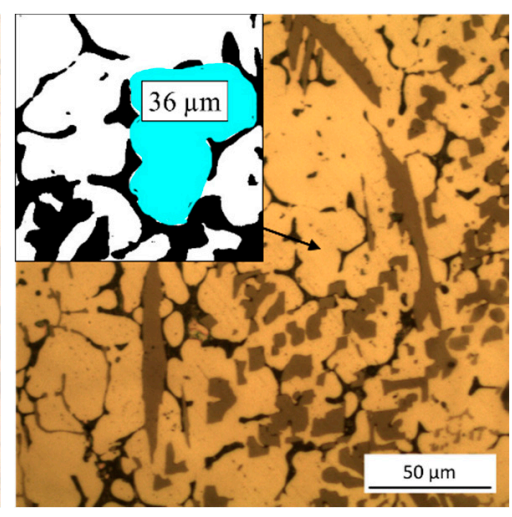

(b)

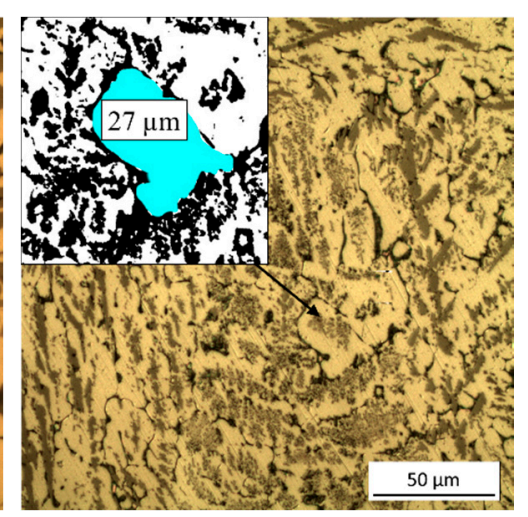

(c)

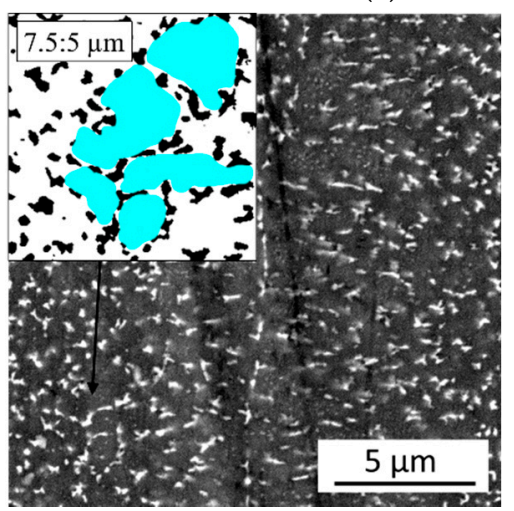

(e)

Figure 4. Microstructures of the Al8Zn7Ni3Mg alloy after solidification at different cooling rates, including binary imaging used for dendritic parameter determination: (a) furnace-cooled (FC) sample; (b) $30 \mathrm{~mm}$ cast sample; (c) $5 \mathrm{~mm}$ cast sample; (d) $1 \mathrm{~mm}$ cast sample; (e) melt spinning (MS) sample.

The microstructure of the FC sample (Figure 4a) can be qualified as the nearest to the equilibrium one. During in-furnace solidification, a large fraction of imposingly coarse primary crystals of up to $351 \mu \mathrm{m}$ can be observed, which are probably responsible for a low ductility of material under such condition. The presented pattern reliably agrees with a schematic one shown in Figure $2 \mathrm{~b}$. The primary $\mathrm{Al}_{3} \mathrm{Ni}_{\mathrm{P}}$ crystals are in an equilibrium with the eutectic mixture $\left[(\mathrm{Al})+\mathrm{Al}_{3} \mathrm{Ni}_{\mathrm{E}}\right]$ in which the eutectic-origin particles are relatively small (medium size $12 \mu \mathrm{m}$ ).

Considering the structure of gravity cast samples, we managed to achieve a significant difference among their solidification conditions and cooling rates as well. The cooling rate of $17 \mathrm{~K} / \mathrm{s}$ for the $30 \mathrm{~mm}$ cast sample (Figure $4 \mathrm{~b}$ ) was calculated using equation 1 and a dendritic parameter of around $39 \mu \mathrm{m}$. The conception of the microstructure does not look modified in comparison to the furnace-cooled sample, but the refinement is obvious from the scale and increased number of dendritic cells reduced fivefold in size along with dramatically reduced intermetallics. 
A further increase in the cooling rate resulted in intermetallic bands formation that indicates a closeness of the solidification path to the eutectic one. In the $5 \mathrm{~mm}$ cast sample (Figure $4 \mathrm{c}$ ), there is still an extremely high number of $\mathrm{Al}_{3} \mathrm{Ni}$ needle-like primary intermetallics, halved in size, obtained via near-rapid cooling $\left(d \sim 20 \mu \mathrm{m}, V_{c}=133 \mathrm{~K} / \mathrm{s}\right)$. Meanwhile, the $1 \mathrm{~mm}$ cast sample $(d \sim 10 \mu \mathrm{m}$, $V_{c}=1.4 \times 10^{3} \mathrm{~K} / \mathrm{s}$ ) contains wide areas where the coupled growth of $\mathrm{Al}_{3} \mathrm{Ni}$ and the (Al) solid solution was provided (Figure $4 \mathrm{~d}$ ). This as qualified quasi-eutectic structure consists of micron-scale intermetallics, mixed with a hypoeutectic structure in vicinity, allowed to estimate the dendritic parameter. Such inhomogeneous structure is probably due to different crystallization front and related to a tough experimental condition. The quasi-eutectic structure is believed to develop via the following solidification path [43-45]. The $\mathrm{Al}_{3} \mathrm{Ni}$ phase as part of the eutectic $\left[(\mathrm{Al})+\mathrm{Al}_{3} \mathrm{Ni}\right]$ nucleates first due to its higher melting point. Next, the $(\mathrm{Al})$ solid solution nucleates in the nickel depleted zone around the $\mathrm{Al}_{3} \mathrm{Ni}$ particles preventing its growth. Therefore, the residual liquid phase is enriched with the nickel until its composition reaches the eutectic point. Thus, the reciprocal growth of both the $\mathrm{Al}_{3} \mathrm{Ni}$ phase and the $(\mathrm{Al})$ solid solution occurs.

In contrast, under melt spinning conditions, the highest cooling rate was achieved resulting in an ultrafine microstructure with visible dendritic cells of about $1.5 \mu \mathrm{m}$ (Figure $4 \mathrm{e}$ ). The estimated cooling rate is $2.3 \times 10^{5} \mathrm{~K} / \mathrm{s}$, which agrees with literature data [22]. The quasi-eutectic-origin intermetallics of submicron size are located along (Al) solid solution dendritic cells and the ultimate structure looks hypoeutectic. However, some areas are revealed to have very small in-bulks particles, which are to be studied using a high-magnification technique.

The microstructure of the $5 \mathrm{~mm}$ cast sample was studied in detail (Figure 5). According to EMPA analysis (Figure $5 \mathrm{~b}$ ), the white phase (in Figure $5 \mathrm{a}$ ) corresponds to an insoluble $\mathrm{Al}_{3} \mathrm{Ni}$ phase with a homogenous composition of $76 \% \mathrm{Al}$ and $24 \% \mathrm{Ni}$. In the vicinity, $\mathrm{T}$ phase veins are clearly observed. It is striking that the most part of the $\mathrm{Zn}$ and $\mathrm{Mg}$ are dissolved in the $(\mathrm{Al})$ matrix even under cooling at $133 \mathrm{~K} / \mathrm{s}$. Hence, it is reasonable to anticipate a dramatic extension of solid solubility in samples obtained at higher cooling rates.

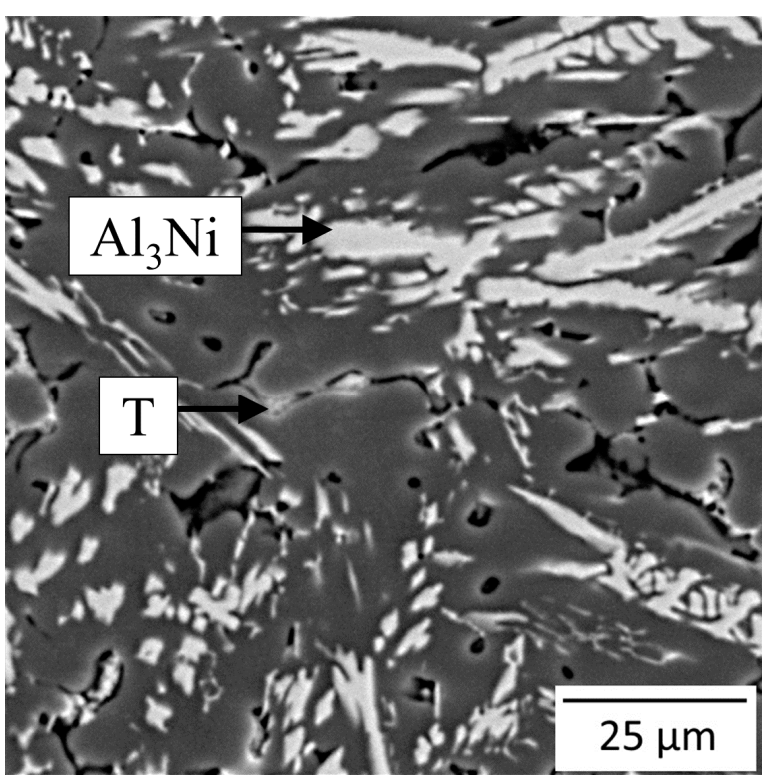

(a)

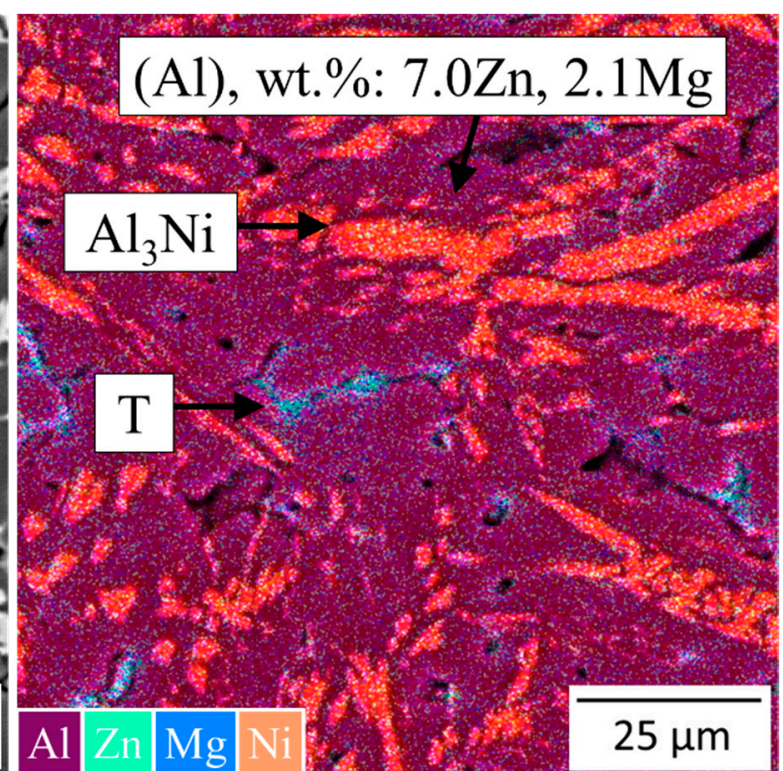

(b)

Figure 5. Microstructure of the $5 \mathrm{~mm}$ cast sample of the Al8Zn7Ni3Mg alloy: (a) SEM; (b) multilayer elemental map.

Ultimately, the analysis of the structure revealed a significant deviation of the solidification path from a local equilibrium condition. Microstructural peculiarities (dendritic cells and intermetallics) were far much refined under an increase in the cooling rate, and their characterization in the samples 
after a cooling rate of more than $10^{3} \mathrm{~K} / \mathrm{s}$ requires for detailed analysis using higher magnification. Preliminary, it is believed that a needle-like $\mathrm{Al}_{3} \mathrm{Ni}$ phase, occurring in the structure of the $\mathrm{FC}, 30 \mathrm{~mm}$, and $5 \mathrm{~mm}$ cast samples, is responsible for brittle behavior, while globular particles presented in other samples could play a reinforcing role in enhancing strength without a substantial loss of ductility. Moreover, the supersaturation of the $(\mathrm{Al})$ solid solution is expected and will be discussed upon the hardness measurement results.

\subsection{Characterization of the Quasi-Eutectic Structure}

In the microstructure of the $1 \mathrm{~mm}$ cast sample (Figure 6), the tough casting condition resulted in the shrinkage cavities formation along the grains. There is no primary phase detected, and the structure seems to be homogeneous and quasi-eutectic in general. As can be seen, the $\mathrm{Al}_{3} \mathrm{Ni}$ eutectic bands are in the bulk of the (Al) solid solution, and in their vicinities, $\mathrm{Zn}$ and $\mathrm{Mg}$ rich areas are presented with an $\mathrm{Al}-8.7 \% \mathrm{Zn}-3.4 \% \mathrm{Mg}$ composition. This result virtually agrees with a previously calculated (Al) matrix composition at $470{ }^{\circ} \mathrm{C}$ and corresponds to a supersaturated condition. The magnified section of the $\left[(\mathrm{Al})+\mathrm{Al}_{3} \mathrm{Ni}\right]$ eutectic band shows that it has a rather fibrous morphology with a linear size of up to $3 \mu \mathrm{m}$. These microstructure features exhibit a correspondence to fiber-reinforced metal matrix composites, so it probably yields the best load transfer efficiency.

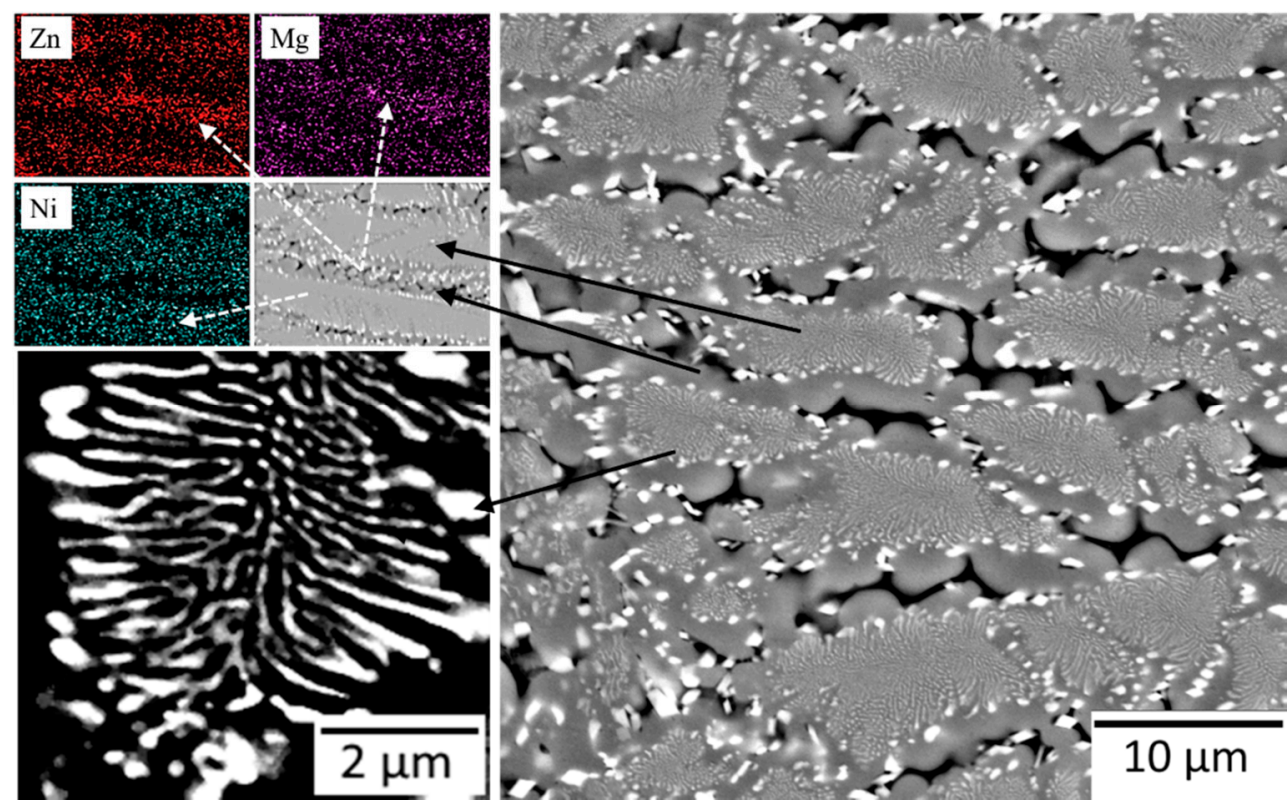

Figure 6. Microstructure of the Al8Zn7Ni3Mg alloy after solidification at $1.4 \times 10^{3} \mathrm{~K} / \mathrm{s}$.

Figure 7 displays the TEM characterization of the structure appearing in the melt-spun ribbons. As can be seen from Figure 7a, it is conceptually similar to the quasi-eutectic structure of the $1 \mathrm{~mm}$ cast sample, because it also shows wide bands of the fine intermetallics, surrounded by dendritic bulks of (Al) solid solution, which are clearly seen in Figure 7b. Since the dendritic cells presented are less than $300 \mathrm{~nm}$ in size, we can assume that the cooling rate achieved in some areas was much higher than $\sim 10^{6} \mathrm{~K} / \mathrm{s}$, probably provided by greater thermal conductivity of the aluminum matrix than intermetallics. The incoherent equiaxed $\mathrm{Al}_{3} \mathrm{Ni}$ particles with a median linear size of $50 \mathrm{~nm}$ are located within the (Al) matrix (Figure 7c). The dark field image (Figure 7d) served as a more contrasting image for inter-particles spacing estimation. Its value is in the 10-50 nm range, which, in turn, shows good promise for a contribution into strength along with precipitate shearing due to possible naturally or artificially triggered decomposition of the (Al) solid solution. 


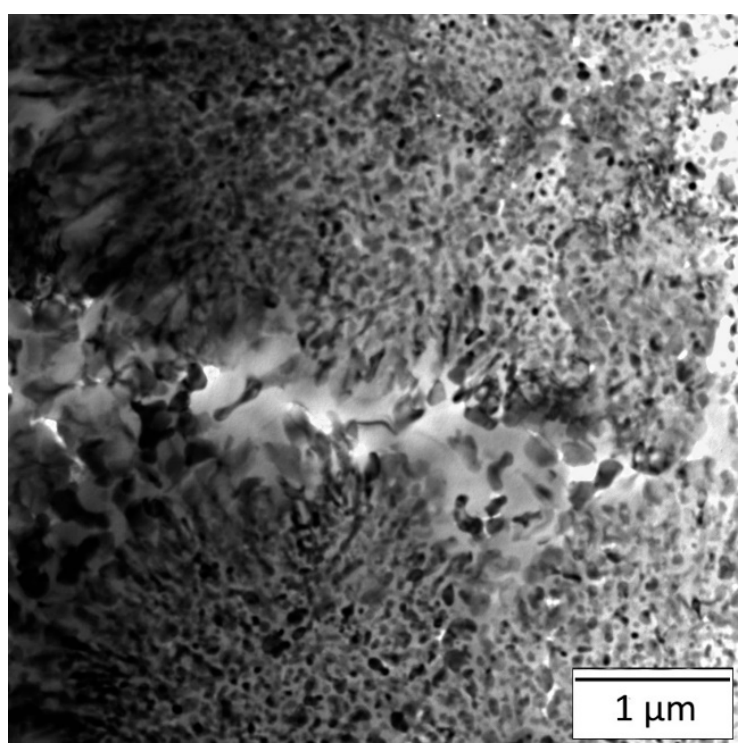

(a)

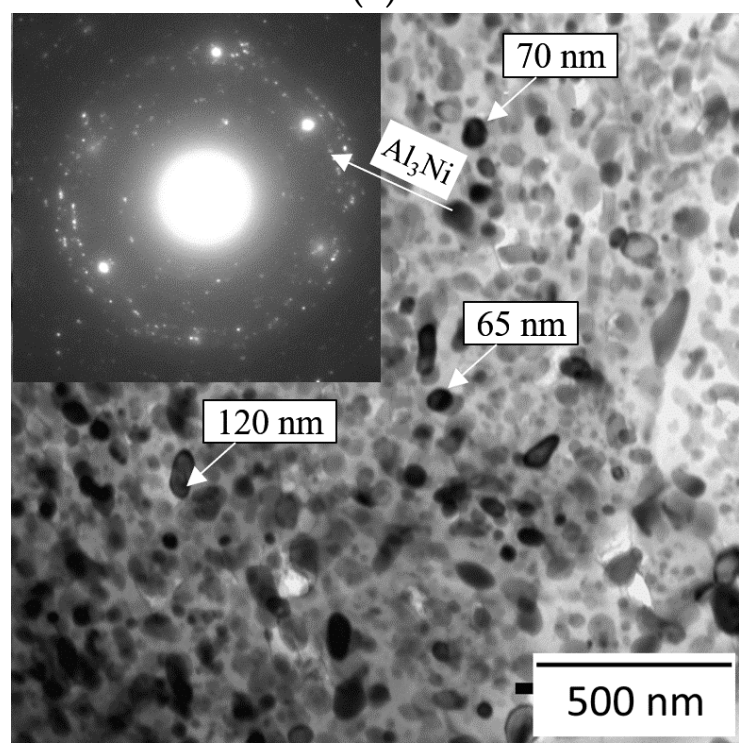

(c)

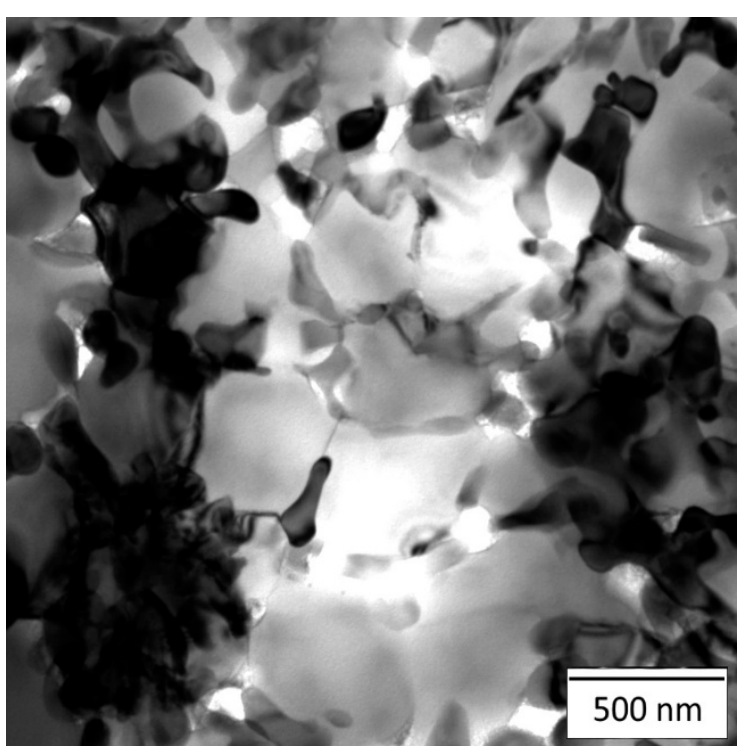

(b)

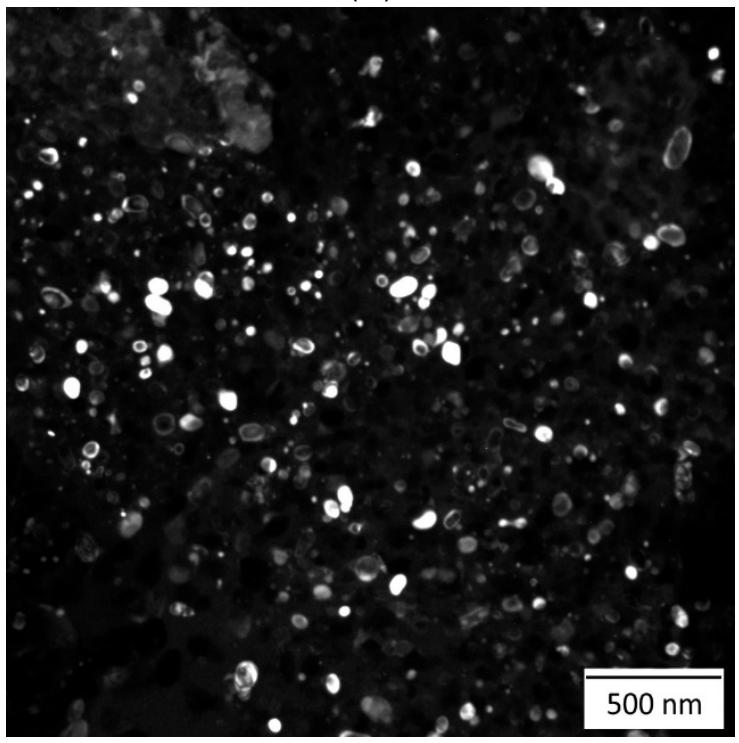

(d)

Figure 7. Microstructure of the melt-spun ribbons (MS sample, $2.3 \times 105 \mathrm{~K} / \mathrm{s}$ ) of the Al8Zn7Ni3Mg alloy: (a) general view of the intermetallic bands; (b) a (Al) dendritic structure appeared in the bands' vicinities; (c) light field image of the globular intermetallcs' band; (d) dark field image.

\subsection{Hardness and Influence of Heat Treatment}

The results of the hardness measurement are shown in Figure 8. As it was earlier shown, the FC sample comprises of primary intermetallics of significantly giant linear size, and therefore, the hardness of $52 \mathrm{HV}$ presented reflects the footprint after indentation into the (Al) matrix. Hence, the nickel contribution is relatively low, as well as the hardness value. A further increase in the cooling rate causes a strong visible effect on the hardness value. For comparison, it increased twofold in the $30 \mathrm{~mm}$ cast sample and threefold in the $5 \mathrm{~mm}$ and $1 \mathrm{~mm}$ samples. The most value of $195 \mathrm{HV}$ was achieved in melt-spun ribbons, which have the finest virtually qualified nanocomposite microstructure. Furthermore, it is worth considering that the most uniform distribution of the hardness values was obtained in cast samples, while the inhomogeneous structure of the $1 \mathrm{~mm}$ cast sample provided high deviation, as well as for the MS sample measured using far lower load due to brittleness. 


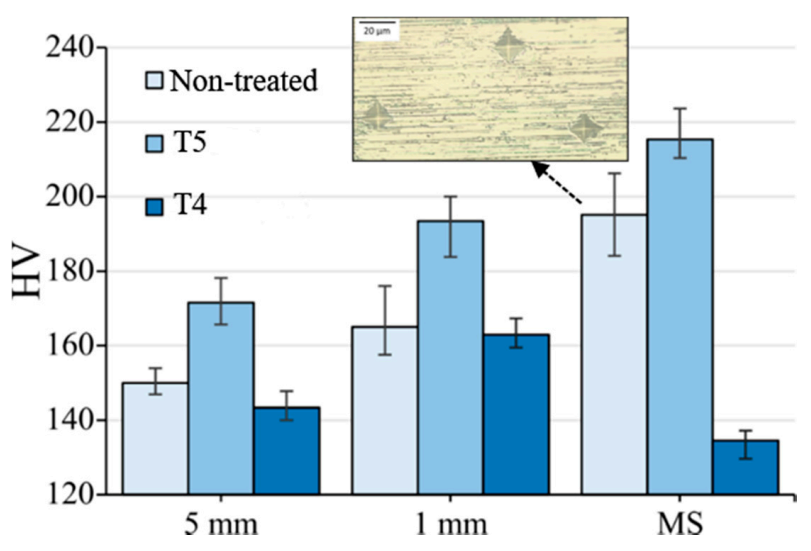

Figure 8. Influence of heat treatment on the hardness of experimental samples of the Al8Zn7Ni3Mg alloy.

Thermal treatment causes significant changes in microstructure and hardness, respectively. The bar chart demonstrates a relatively high aging response of around $20 \mathrm{HV}$ at $200{ }^{\circ} \mathrm{C}$ without preliminary quenching in $5 \mathrm{~mm}$ and $1 \mathrm{~mm}$ cast samples as well as the MS sample. It is striking that the MS sample initially has a hardness of $200 \mathrm{HV}$, which is the same as an aged $1 \mathrm{~mm}$ cast sample. However, further aging leads to an increase in values of up to $220 \mathrm{HV}$, corresponding to ultrahigh-strength Al-based materials [10]. However, a further increase in temperature to $470{ }^{\circ} \mathrm{C}$ leads to a significant degradation of hardness. For all samples this is due to the (Al) matrix solutionization during alloy solidification. Moreover, for a composite-structured $1 \mathrm{~mm}$ cast sample and MS samples, this loss of properties is caused by a significant degradation of the intermetallics morphology.

The degradation of the $\mathrm{Al}_{3} \mathrm{Ni}$ phase morphology after a $470{ }^{\circ} \mathrm{C}$ heat treatment is highly dependent on the initial microstructure. As the as-cast $1 \mathrm{~mm}$ sample microstructure contains fiber-like, slightly elongated inclusions, they were conjugated along a definite crystallographic plane, resulting in significant shape deformation as a mixture of needles and coalescenced particles, both blocky for load transfer (Figure 9a). Meanwhile, the MS sample initially contained equiaxed intermetallics, and heating to $470{ }^{\circ} \mathrm{C}$ caused advanced coalescence. The particles size is ranged in $0.2-2.5 \mu \mathrm{m}$, but their roundness is apparently appropriate to be $0.8-1$ for $90 \%$ of the whole volume (Figure $9 \mathrm{~b}$ ). This factor seems to be advantageous in terms of hot consolidation of the melt-spun ribbons, hence, the microstructure of the bulk products may still be qualified as a reinforced composite.

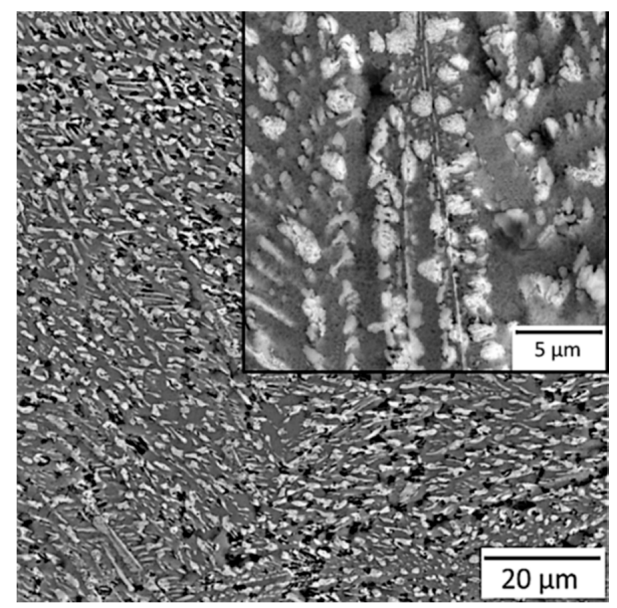

(a)

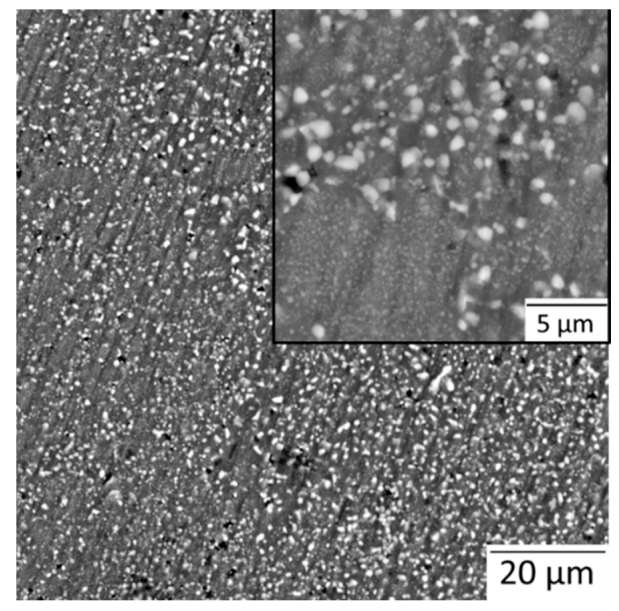

(b)

Figure 9. Microstructure of the Al8Zn7Ni3Mg alloy after $470{ }^{\circ} \mathrm{C}$ heat treatment: (a) $1 \mathrm{~mm}$ cast sample; (b) MS sample. 


\section{Conclusions}

By using computational and experimental studies, the effect of different cooling rates $(0.1 \mathrm{~K} / \mathrm{s}$, $17 \mathrm{~K} / \mathrm{s}, 133 \mathrm{~K} / \mathrm{s}, 1.4 \times 10^{3} \mathrm{~K} / \mathrm{s}$, and $2.3 \times 10^{5} \mathrm{~K} / \mathrm{s}$ ) on the phase composition, solidification manner, microstructure, and hardness of the Al8Zn7Ni3Mg aluminum alloy has been analyzed in details. The tremendous refinement of the microstructure along with extension in $\mathrm{Zn}$ and $\mathrm{Mg}$ solid solubility was accompanied with increase in hardness as a result of solidification path shift from a hypereutectic to a eutectic and hypoeutectic one. The results are believed to be beneficial for the development of new high-strength particulate reinforced composites which do not require ex-situ intervention for the input of reinforcements. Moreover, when considering eutectic forming element addition, a decrease in hot embrittlement is anticipated. Hence, the new composition may be highly recommended for laser additive manufacturing applications. The major conclusions are as follows:

(1) By using the CALPHAD approach, the concentration of nickel in the experimental Al8Zn7Ni3Mg alloy has been justified. While the eutectic point in the $\mathrm{Al}-8 \% \mathrm{Zn}-3 \% \mathrm{Mg}-\mathrm{Ni}$ system corresponds to $3.6 \% \mathrm{Ni}$, the $7 \% \mathrm{Ni}$ composition is highly hypereutectic. Taking into account the opportunity to shift the solidification path with further refinement caused by increase in cooling rates, the experimental alloy comprises $12.8 \mathrm{vol} . \% \mathrm{Al}_{3} \mathrm{Ni}$ intermetallics in which half corresponds to the primary phase;

(2) Composition of the (Al) solid solution after rapid solidification has been simulated similar to the one at the $470{ }^{\circ} \mathrm{C}$ solid solution temperature. The higher the nickel content, the more saturated the $(\mathrm{Al})$ matrix. It is shown that a $7 \% \mathrm{Ni}$ concentration is advantageous in terms of obtaining supersaturated solid solution containing $9.6 \% \mathrm{Zn}$ and $3.6 \% \mathrm{Mg}$, promoting precipitation of $9.6 \mathrm{vol} . \%$ of $\mathrm{T}^{\prime}$ and $\mathrm{M}^{\prime}$ dispersoids. Meanwhile, a higher amount of nickel does not provide a significant change in these values;

(3) By OM, SEM, and TEM analysis, the increase in cooling rates on the microstructure was investigated, showing profound opportunities for microstructure tuning. A highly hypereutectic structure was observed after solidification at $0.1 \mathrm{~K} / \mathrm{s}, 17 \mathrm{~K} / \mathrm{s}$, and $133 \mathrm{~K} / \mathrm{s}$ accompanied with a refinement of the $\mathrm{Al}_{3} \mathrm{Ni}$ phase from 50 to $7 \mu \mathrm{m}$ in medium size. A cooling rate of $1.4 \times 10^{3} \mathrm{~K} / \mathrm{s}$ appeared to be sufficient for providing quasi-eutectic solidification manner, and most of the structure area is covered with fiber-like composite microstructure of $1.5 \mu \mathrm{m}$ intermetallics, while the melt spinning provided a cooling rate of $2.3 \times 10^{5} \mathrm{~K} / \mathrm{s}$ resulting in a visible hypoeutectic structure with ultrafine equiaxed $50 \mathrm{~nm}$ intermetallics in the (Al) matrix bulk, beneficial for looping reinforcing;

(4) The hardness test revealed a substantial increase in strengthening as a result of structure refinement. While in slow and conventionally-cooled samples the hardness of 50-150 HV is relatively not contributed by $\mathrm{Al}_{3} \mathrm{Ni}$ intermetallics appearance, the rapidly solidified samples showed a significant enhancement of $165 \mathrm{HV}$ in the $1 \mathrm{~mm}$ cast sample and $195 \mathrm{HV}$ in melt-spun ribbons. Moreover, these samples both showed a significant strengthening after low temperature annealing at $200^{\circ} \mathrm{C}$, achieving up to $220 \mathrm{HV}$;

(5) Nonetheless, a solid solution treatment at $470{ }^{\circ} \mathrm{C}$ resulted in significant degradation of hardness. While the $1 \mathrm{~mm}$ cast sample saw a decrease to the initial level, the melt-spun sample degraded to obtain hardness of around $140 \mathrm{HV}$. Such a loss in properties is caused by structure coarsening. Meanwhile, the fibrous-like intermetallics coalescenced to become needles and rods (up to $10 \mu \mathrm{m}$ ), and the globular particles evolved remaining a high roundness and relatively low size $(0.2-2.5 \mu \mathrm{m})$, which is promising in terms of further consolidation processing.

Author Contributions: Conceptualization, P.S. and T.A.; investigation, N.K. and A.P.; methodology, A.P., A.B., and A.K.; resources, A.P., A.K., D.M., and A.B.; supervision, T.A.; writing-original draft, P.S.; writing一review \& editing, P.S. and T.A. All authors have read and agreed to the published version of the manuscript.

Funding: This research was funded by the Russian Science Foundation (project No. 19-79-30025). 
Acknowledgments: The authors would like to thank Mikhail Gorshenkov for providing TEM investigations.

Conflicts of Interest: The authors declare no conflict of interest.

\section{References}

1. Polmear, I.; StJohn, D.; Nie, J.-F.; Qian, M. Physical metallurgy of aluminium alloys. In Light Alloys, 5th ed.; Elseiver: London, UK, 2017; pp. 31-107. [CrossRef]

2. Starke, E.A., Jr.; Staley, J.T. Application of modern aluminium alloys to aircraft. In Fundamentals of Aluminium Metallurgy; Lumley, R., Ed.; Woodhead Publishing Limited: Cambridge, UK, 2011; pp. 747-783. [CrossRef]

3. Ditta, A.; Weia, L.; Xub, Y.; Wua, S. Microstructural characteristics and properties of spray formed Zn-rich Al-Zn-Mg-Cu alloy under various aging conditions. Mater. Charact. 2020, 161, 110133. [CrossRef]

4. Zhao, J.; Liu, Z.; Bai, S.; Zeng, D.; Luo, L.; Wang, J. Effects of natural aging on the formation and strengthening effect of G.P. zones in a retrogression and re-aged Al-Zn-Mg-Cu alloy. J. Alloys Compd. 2020, 829, 154469. [CrossRef]

5. Chen, Z.; Yuan, Z.; Ren, J. The mechanism of comprehensive properties enhancement in Al-Zn-Mg-Cu alloy via novel thermomechanical treatment. J. Alloys Compd. 2020, 828, 154446. [CrossRef]

6. Tamarin, Y. Atlas of Stress-Strain Curves, 2nd ed.; ASM International: Novelty, OH, USA, 2002.

7. Peng, G.; Tietao, Z.; Xiaoqing, X.; Zhi, G.; Li, C. Refinement mechanism research of $\mathrm{Al}_{3} \mathrm{Ni}$ phase in Ni-7050 alloy. Rare Met. Mater. Eng. 2013, 42, 6-13. [CrossRef]

8. Aoi, I.; Kuramoto, S.; Oh-ishi, K. Mechanical properties of Al-(8,10)\%Zn-2\%Mg-2\%Cu base alloys processed with high-pressure torsion. Light Met. 2015, 179-182. [CrossRef]

9. Ibrahim, M.F.; Samuel, A.M.; Alkahtani, S.A.; Samuel, F.H. A novel solution heat treatment of 7075-type alloy. Light Met. 2013, 383-390. [CrossRef]

10. Wang, W.; Pana, Q.; Wanga, X.; Sun, Y.; Long, L.; Huang, Z. Mechanical properties and microstructure evolution of ultra-high strength Al-Zn-Mg-Cu alloy processed by room temperature ECAP with post aging. Mater. Sci. Eng. A 2018, 731, 195-208. [CrossRef]

11. Elliot, R. Eutectic Solidification Processing: Crystalline and Glassy Alloys, 1st ed.; Butterworth-Heinemann: Oxford, UK, 1983. [CrossRef]

12. Kim, C.S.; Cho, K.; Manjili, M.H.; Nezafati, M. Mechanical performance of particulate-reinforced Al metal-matrix composites (MMCs) and Al metalmatrix nano-composites (MMNCs). J. Mater. Sci. 2017, 52, 13319-13349. [CrossRef]

13. Zhang, Z.; Chen, D.L. Contribution of Orowan strengthening effect in particulate-reinforced metal matrix nanocomposites. Mater. Sci. Eng. A 2008, 483-484, 148-152. [CrossRef]

14. Garces, G.; Bruno, G.; Wanner, A. Load transfer in short fibre reinforced metal matrix composites. Acta Mater. 2007, 55, 5389-5400. [CrossRef]

15. Garg, P.; Jamwal, A.; Kumar, D.; Sadasivuni, K.K.; Hussain, C.M.; Gupta, P. Advance research progresses in aluminium matrix composites: Manufacturing \& applications. J. Mater. Res. Tech. 2019, 8, 4924-4939. [CrossRef]

16. Chung, D.D.L. Metal-Matrix Composites. In Carbon Composites, 2nd ed.; Elseiver: London, UK, 2017; pp. 532-562. [CrossRef]

17. Dinaharan, I. Liquid metallurgy processing of intermetallic matrix composites. In Intermetallic Matrix Composites; Mitra, R., Ed.; Elseiver: London, UK, 2017; pp. 167-202. [CrossRef]

18. Gao, T.; Bian, Y.; Li, Z.; Xu, Q.; Yang, H.; Zhao, K.; Liu, X. Synthesis of a $\left(\mathrm{ZrAl}_{3}+\mathrm{AlN}\right) / \mathrm{Al}$ composite and the influence of particles content and element $\mathrm{Cu}$ on the microstructure and mechanical properties. J. Alloys Compd. 2019, 791, 730-738. [CrossRef]

19. Najarian, A.R.; Emadi, R.; Hamzeh, M. Fabrication of as-cast $\mathrm{Al}$ matrix composite reinforced by $\mathrm{Al}_{2} \mathrm{O}_{3} / \mathrm{Al}_{3} \mathrm{Ni}$ hybrid particles via in-situ reaction and evaluation of its mechanical properties. Mater. Sci. Eng. B 2018, 231, 57-65. [CrossRef]

20. Bao, S.; Tang, K.; Kvithyld, A.; Engh, T.; Tangstad, M. Wetting of pure aluminium on graphite, $\mathrm{SiC}$ and $\mathrm{Al}_{2} \mathrm{O}_{3}$ in aluminium filtration. Trans. Nonferrous Met. Soc. China 2012, 22, 1930-1938. [CrossRef] 
21. Cai, Z.; Zhang, C.; Wang, R.; Peng, C.; Wu, X.; Li, H. Microstructure, mechanical and thermo-physical properties of Al-50Si-xMg alloys. Mater. Sci. Eng. A 2018, 730, 57-65. [CrossRef]

22. Dobatkin, V.I.; Elagin, V.I.; Fedorov, V.M. Structure of rapidly solidified aluminium alloys. Adv. Perform. Mater. 1995, 2, 89-98. [CrossRef]

23. Uzun, O.; Karaaslan, T.; Gogebakan, M.; Keskin, M. Hardness and microstructural characteristics of rapidly solidified Al-8-16 wt.\%Si alloys. J. Alloys Compd. 2004, 376, 149-157. [CrossRef]

24. Cai, Z.; Zhang, C.; Wang, R.; Peng, C.; Qiu, K.; Feng, Y. Preparation of Al-Si alloys by a rapid solidification and powder metallurgy route. Mater. Des. 2015, 87, 996-1002. [CrossRef]

25. Hatch, J.E. Aluminium: Properties and Physical Metallurgy; American Society for Metals: Cleveland, $\mathrm{OH}$, USA, 1984.

26. The Aluminium Association, International Alloy Designations and Chemical Composition Limits for Wrought Aluminium and Wrought Aluminium Alloys. The Aluminium Association. Available online: https://www.aluminum.org/sites/default/files/Teal\%20Sheets.pdf (accessed on 26 April 2020).

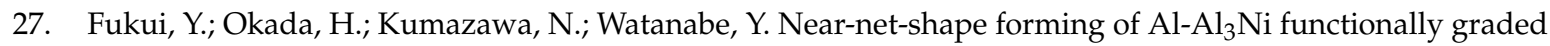
material over eutectic melting temperature. Met. Mater. Trans. A 2000, 31, 2627-2636. [CrossRef]

28. Nash, P.; Pan, Y.Y. The Al-Ni-Zr system (Aluminium-Nickel-Zirconium). J. Phase Equilibria 1991, 12, $105-113$. [CrossRef]

29. Belov, N.A.; Zolotorevskiy, V.S. The Effect of nickel on the structure, mechanical and casting properties of aluminium alloy of 7075 type. Mater. Sci. Forum 2002, 396-402, 935-940. [CrossRef]

30. Belov, N.A.; Cheverikin, V.V.; Eskin, D.G.; Turchin, A.N. Effect of $\mathrm{Al}_{3} \mathrm{Ni}$ and $\mathrm{Mg}_{2} \mathrm{Si}$ eutectic phases on casting properties and hardening of an Al-7\%Zn-3\%Mg alloy. Mater. Sci. Forum 2006, 519-521, 413-418. [CrossRef]

31. Wang, S.H.; Uan, J.Y.; Lui, T.S.; Chen, L.H. Examination on the aging and tensile properties of $\mathrm{Al}-\mathrm{Zn}-\mathrm{Mg} / \mathrm{Al}_{3} \mathrm{Ni}$ eutectic composite. Met. Mater. Trans. A 2002, 33, 707-711. [CrossRef]

32. Barclay, R.S.; Kerr, H.W.; Niessen, P. Off-eutectic composite solidification and properties in Al-Ni and Al-Co alloys. J. Mater. Sci. 1971, 6, 1168-1173. [CrossRef]

33. Martínez-Villalobos, M.A.; Figueroa, I.A.; Suarez, M.A.; Rodríguez, G.A.L.; Peralta, O.N.; Reyes, G.G.; López, I.A.; Martínez, J.V.; Trujillo, C.D. Microstructural Evolution of Rapid Solidified Al-Ni Alloys. J. Mex. Chem. Soc. 2016, 60, 67-72. [CrossRef]

34. Lin, Y.; Mao, S.; Yan, Z.; Zhang, Y.; Wang, L. The enhanced microhardness in a rapidly solidified Al alloy. Mater. Sci. Eng. A 2017, 692, 182-191. [CrossRef]

35. Casati, R.; Coduri, M.; Riccio, M.; Rizzi, A.; Vedani, M. Development of a high strength Al-Zn-Si-Mg-Cu alloy for selective laser melting. J. Alloys Compd. 2019, 801, 243-253. [CrossRef]

36. Belov, N.A. Sparingly alloyed high-strength aluminium alloys: Principles of optimization of phase composition. Mater. Sci. Heat Tr. 2012, 53, 19-27. [CrossRef]

37. Thermo-Calc Software TTAL5 Al-Alloys. Available online: http://www.thermocalc.com (accessed on 17 April 2020).

38. Neikov, O.D.; Naboychenko, S.S.; Yefimov, N.A. Handbook of Non-Ferrous Metal Powders: Technologies and Applications, 2nd ed.; Elseiver: London, UK, 2018; p. 995. [CrossRef]

39. Nishi, M.; Matsuda, K.; Miura, N.; Watanabe, K.; Ikeno, S.; Yoshida, T.; Murakami, S. Effect of the Zn/Mg ratio on microstructure and mechanical properties in Al-Zn-Mg alloys. Mater. Sci. Forum 2014, 794-796, 479-482. [CrossRef]

40. Galy, C.; Le Guen, E.; Lacoste, E.; Arvieu, C. Main defects observed in aluminium alloy parts produced by SLM: From causes to consequences. Addit. Manuf. 2018, 22, 165-175. [CrossRef]

41. Glazoff, M.; Khvan, A.; Zolotorevsky, V.; Belov, N.; Dinsdale, A. Casting Aluminium Alloys: Their physical and Mechanical Metallurgy, 2nd ed.; Elsevier: Amsterdam, The Netherlands, 2018. [CrossRef]

42. Grandfield, J.; Eskin, D.G.; Bainbridge, I. Direct-Chill Casting of Light Alloys: Science and Technology, 1st ed.; John Wiley \& Sons, Inc.: Hoboken, NJ, USA, 2013.

43. Todeschini, P.; Champier, G.; Samuel, F.H. Production of Al-(12-25) wt\% Si alloys by rapid solidification: Melt spinning versus centrifugal atomization. J. Mater. Sci. 1992, 27, 3539-3551. [CrossRef] 
44. Ma, P.; Prashanth, K.G.; Scudino, S.; Jia, Y.; Wang, H.; Zou, C.; Wei, Z.; Eckert, J. Influence of Annealing on Mechanical Properties of Al-20Si Processed by Selective Laser Melting. Metals 2014, 4, 28-36. [CrossRef]

45. Lekatou, A.; Sfikas, A.K.; Petsa, C.; Karantzalis, A.E. Al-Co alloys prepared by vacuum arc melting: Correlating microstructure evolution and aqueous corrosion behavior with Co content. Metals 2016, 6, 46. [CrossRef] 